九州大学学術情報リポジトリ

Kyushu University Institutional Repository

\title{
Studies on Lipid Changes During the Development of Frost Hardiness in Chlorella ellipsoidea
}

Kabata, Kiyotaka

Laboratory of Food Hygienic Chemistry, Faculty of Agriculture, Kyushu University

Sadakane, Haruo

Laboratory of Food Hygienic Chemistry, Faculty of Agriculture, Kyushu University

Miyachi, Masahiro

Laboratory of Food Hygienic Chemistry, Faculty of Agriculture, Kyushu University

Nagata, Kiyoshi

Laboratory of Food Hygienic Chemistry, Faculty of Agriculture, Kyushu University

他

https://doi.org/10.5109/23687

出版情報：九州大学大学院農学研究院紀要. 23 (3/4)，pp. 155-161，1979-03. Kyushu University バージョン：

権利関係 : 


\title{
Studies on Lipid Changes During the Development of Frost Hardiness in Chlorella ellipsoidea*
}

\author{
Kiyotaka Kabata, Haruo Sadakane, Masabiro Miyachi, \\ Kiyoshi Nagata**, Shoji Hatano and Tadao Watanabe \\ Laboratory of Food Hygienic Chemistry, Faculty of Agriculture, \\ Kyushu University 46-09, Fukuoka 812
}

(Received November 24. 1978)

\begin{abstract}
Chlorella ellipsoidea cells at an intermediate stage in the ripening phase of the cell cycle were hardened at $3^{\circ} \mathrm{C}$ for $48 \mathrm{hr}$. Lipid changes during the development of frost hardiness were measured. Phospholipids and glycolipids increased from 0.4 $\mu$ moles to $1.2 \mu$ moles $/ 10^{\circ}$ cells and from $0.9 \mu$ moles to $1.6 \mu$ moles $/ 10^{9}$ cells, respectively. The ratio of lipid $(\mathrm{mg}) /$ protein $(\mathrm{mg})$ in hardened cells was about 1.4 times that in unhardened cells. These results suggest that the algal cells change into more lipid-enriched state during the development of frost hardiness and that considerable change in lipid metabolism is involved in the development of the algal hardiness. Moreover, the ratios of individual phospholipids to monogalactosyl diglyceride tended to increase during the hardening process. Non-polar lipid which remarkatly increased with an increase in frost hardiness was detected. According to studies on inhibitory effect of oligomycin or 3-(3,4-dichlorophenyl)1,1-dimethylurea on the increase of frost hardiness, the non-polar lipid was always synthesized whenever the algal cells developed the frost hardiness. These results suggest the existence of an intimate correlation between the content of the non-polar lipid and frost hardiness and the importance of the non-polar lipid in lipid metabolism associated with the hardiness change in Chlorella.
\end{abstract}

\section{INTRODUCTION}

Many biochemical studies have indicated that various cells in higher plants undergo profound lipid changes associated with the frost hardiness. Quantity of phospholipids (Siminovitch et al., 1968; Yoshida and Sakai, 1973) and increase in unsaturation of fatty acids (Kuiper, 1970; de la Roche et al., 1972) during hardening have been studied intensively. However, little information is available

* Studies on frost hardiness in Chlorella ellipsoidea. Part IV.

** Present address: Ueno Chemical Co. Ltd., Nisinomiya, Hyogo.

\section{ABBREVIATIONS}

MGDG : monogalactosyl diglyceride ; DGDG: digalactosyl diglyceride ; PE: phosphatidyl ethanolamine ; PG: phosphatidyl glycerol; PC: phosphatidyl choline ; SL sulfolipid ; TG: triglyceride; DG: diglyceride; MG: monoglyceride ; FFA: free fatty acid; UK: unknown non-polar lipid; $\beta$-Car.: p-carotene; Phe.: pheophytin ; Chl. A: chlorophyll a; Chl. B: chlorophyll b; Lut.: lutein; OGM: oligomycin; DCMU: 3-(3,4-dichlorophenyl)-1,1-dimethylurea 
on the transition of lipid metabolism during hardening.

Previous studies have demonstrated that Chlorella ellipsoidea Gerneck (IAM C-27) is a hardy plant which can be acclimated by exposure to low temperature (Hatano et al., $1976 \mathrm{a}, \mathrm{b}$ ). It has been suggested that the hardening mechanism in the algal cells is similar to that in higher plants (Hatano et al., 1976 b).The unicellular green alga is a convenient material to study the lipid metabolism associated with the hardening process. We first measured changes of lipid classes associated with frost hardiness.

This paper describes changes in amounts of glycolipids and phospholipids, and that of non-polar lipid which remarkably increases with increase of the algal hardiness.

\section{MATERIALS AND METHODS}

\section{Plant material}

The strain of Chlorella ellipsoidea Gerneck used was the same as that used in the preceding study (Hatano et al., 1976 a). Methods of the culture (at $25^{\circ} \mathrm{C}$, under 9-10 kilolux, with $1 \% \mathrm{CO}_{2}$-air) and synchronization of algal cells (under a 28 -hr light - 14-hr dark regime) have been described previously (Hatano et al., 1976a). Since the cells were most hardened at the $\mathrm{L}_{2}$ stage (an intermediate stage in the ripening phase of the cell cycle), $\mathrm{L}_{2}$ cells were used in this study.

\section{Hardening}

Algal cells synchronized at $25^{\circ} \mathrm{C}$ were directly hardened at $3^{\circ} \mathrm{C}$ for $48 \mathrm{hr}$. During treatment, the culture was kept under a light intensity of 9-10 kilolux and aerated with air containing about $1 \% \mathrm{CO}_{2}$, unless otherwise stated. The inhibitors or glucose added to the culture during hardening were removed prior to freezing by repeated centrifugations as reported previously (Hatano et al., 1976b). The control culture, without inhibitors or glucose, was subjected to the same procedures.

\section{Freezing and thawing}

Freeze-thawing of the cells was performed as described previously (Hatano et al., 1976 a). Five milliliters of the culture in the sterilized test tube, which was set aslant to decrease supercooling, was cooled in an air blast freezer at $-20^{\circ} \mathrm{C}$ for $20 \mathrm{hr}$. The frozen specimen was thawed in a bath kept at $25^{\circ} \mathrm{C}$. The cooling and thawing rates, represented by the time required to change the temperature between $10^{\circ} \mathrm{C}$ and $-10^{\circ} \mathrm{C}$, were about $41 \mathrm{~min}$ and $57 \mathrm{sec}$, respectively.

\section{Determination of viability}

The viability of algal cells was determined with the growth curve on the basis of $A_{420}$. Previous study (Hatano et al., $1976 \mathrm{a}, \mathrm{b}$ ) has demonstrated that the viability determined with the growth curve coincided with that determined by both colony count and packed cell volume. 


\section{Lipid extraction and analysis} (1959).

Lipids were extracted from Chlorella cells as outlined by Bligh and Dyer

The cells harvested by centrifugation were added to hot methanol and boiled for 5 min (Paula and Heath, 1970). This extraction was repeated once more. After cooling and centrifuging, the residue was reextracted with chloroformmethanol (2: 1, v/v). After centrifuging, the combined lipid extracts were washed by water to remove non-lipid contaminants. The chloroform fraction was concentrated by use of a rotary evaporator. Thin-layer chromatography (TLC) plates were prepared with Silica Gel $\mathrm{H}$ and activated for $2 \mathrm{hr}$ at $110^{\circ} \mathrm{C}$. The plates were chromatographed successively according to the method of Hirayama and Matsuda (1972) with two different solvent systems. The first solvent was a mixture of chloroform/methanol/acetic acid/water (70/20/2/2, v/v). The second solvent was a mixture of n-hexane/diethyl ether/acetic acid (90/10/1, $\mathrm{v} / \mathrm{v})$. The band lipids were identified by spray of various color reagents; $\alpha$ naphtol-5 $\% \mathrm{H}_{2} \mathrm{SO}_{4}$ for monogalactosyl diglyceride (MGDG) and digalactosyl di. glyceride (DGDG), ninhydrin for phosphatidyl ethanolamine (PE), Dragendorff's reagent for phosphatidyl choline (PC), Dittmer reagent for phoshatidyl glycerol (PG) and $50 \% \mathrm{H}_{2} \mathrm{SO}_{4}$ for all lipid components. Furthermore, the band lipids were identified by comparison with standard lipids. Pigments were separated with n-hexane/diethyl ether/acetone (60/30/20, v/v) as a developing solvent and identified by the methods of Hirayama and Suzuki (1968). The quantification of lipid classes was achieved by TLC scanner of Shimadzu CS-900 type. Phospholipids and glycolipids were determined according to the method of Shibuya et al. (1967) and that of Dubois et al. (1956), respectively.

Packed cell volume was measured with a hematocrit and dry weight was measured with lyophilized cells.

\section{RESULTS AND DISCUSSION}

Changes in packed cell volume and dry weight during the hardening process at $3^{\circ} \mathrm{C}$ for $48 \mathrm{hr}$ were determined. As Fig. 1-A shows, packed cell volume increased from $0.42 \mathrm{ml}$ to $0.64 \mathrm{ml} /$ liter during the hardening process. Similarly dry weight increased from $17.5 \mathrm{mg}$ to $26 \mathrm{mg} / 10^{9}$ cells. Fig. 1-B shows that protein content in dry weight changed from $29 \%$ to $31 \%$ during the hardening process while lipid content in dry weight changed from $9 \%$ to $13.6 \%$. Therefore, the ratio of lipid $(\mathrm{mg}) /$ protein $(\mathrm{mg})$ in hardened cells is about 1.4 times that in unhardened cells. This result suggests that the algal cells change into more lipid-enriched state during the development of frost hardiness and that considarable change in lipid metabolism is involved in the development of the algal hardiness.

Total lipids and pigments extracted from the algal cells at $L_{2}$ stage were separated by TLC and identified (Fig. 2). B-carotene (P-Car.), chlorophyll a (Chl. A), chlorophyll b (Chl. B), pheophytin (Phe.) and lutein (Lut.) were identified as pigment components. MGDG, DGDG, PE, PG, PC and sulfolipid 


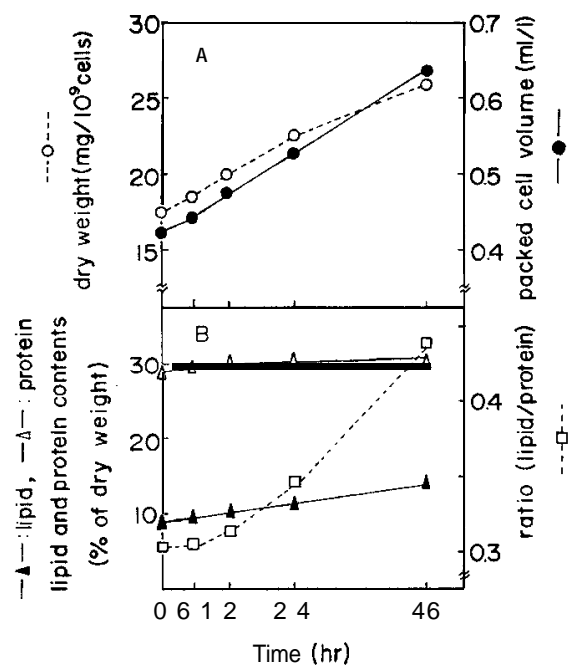

Fig. 1. Changes in packed cell volume, dry weight, lipid and protein contents during the hardening process.

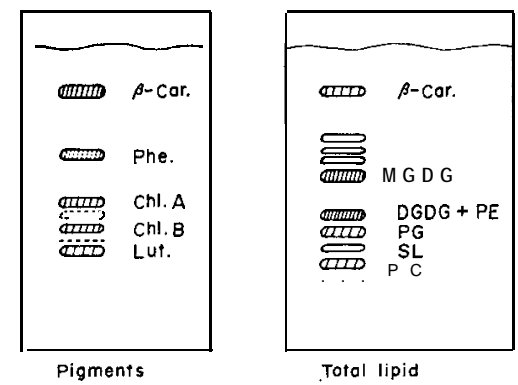

Fig. 2. Thin-layer chromatograms of total lipids and pigments extracted from Chlorella ellipsoidea.

Total lipids were separated on the basis of two different developing solvent systems. The first solvent was a mixture of chloroform/methanol/ acetic acid/water $(70 / 20 / 2 / 2$, v/v $>$. The second solvent was a mixture of $\mathrm{n}$-hexane/ether/acetic acid $(90 / 10 / 1, \mathrm{v} / \mathrm{v})$. Pigments were separated with $\mathrm{n}$-hexane/ether/acetone $(60 / 30 / 20, \mathrm{v} / \mathrm{v})$ as a developing solvent.

(SL) were identified as main lipid components. Yoshida and Suzuki (1973) have suggested that an interconversion between phospholipids and triglyceride was necessary to develop the frost hardiness in cortical cells from poplar stem. However, triglyceride was not identified in the algal cells.

Changes in amounts of phospholipids and glycolipids were measured during the hardening process. As shown in Table 1, glycolipids and phospholipids increased from $0.9 \mu$ moles to $1.6 \mu$ moles $/ 10^{\circ}$ cells and from $0.4 \mu$ moles to 1.2 $\mu$ moles $/ 10^{\circ}$ cells, respectively. Several papers have reported the augmentation of phospholipids associated with the development of frost hardiness in higher plants. The augmentation of phospholipids during hardening was appar- 
ent in Chlorella cells (Table 1). Siminovitch et al. (1968) and de la Roche et al. (1972) concluded, from the results in black locust bark and winter wheat, respectively, that there was the augmentation of phospholipids during frost hardiness but not any preferential synthesis of individual phospholipids. Yoshida and Sakai (1973) have reported that the augmentation of phospholipids during frost hardening of poplar bark was due to an increase in PC and PE. Therefore, changes of lipid composition during the hardening process were determined in Chlorella (Table 2). The ratios of individual lipid components to MGDG increased during the hardening process. Especially, the ratio of the unknown non-polar lipid (UK), which was indicated on TLC of Fig. 3, to MGDG increased among the lipids tested. Therefore, we studied the inhibitory effects of various antimetabolites on the increase of frost hardiness in order to reveal an interrelation between the unknown non-polar lipid content and the hardiness increase.,

Table 1. Changes in amount of glycolipids and phospholipids during the hardening process.

\begin{tabular}{lccccc}
\hline & \multicolumn{5}{c}{ Hardening time $(\mathrm{hr})$} \\
\cline { 2 - 4 } & 0 & $\mathbf{6}$ & $\mathbf{1 2}$ & $\mathbf{2 4}$ & $\mathbf{4 8}$ \\
\hline Glycolipids $\left(\mu\right.$ moles $/ 10^{9}$ cells) & 0.9 & 1.0 & 1.1 & 1.2 & 1.6 \\
Phospholipids ( $\mu$ moles $/ 10^{9}$ cells) & 0.4 & 0.5 & 0.6 & 0.7 & 1.2 \\
\hline
\end{tabular}

Table 2. Changes in lipid composition during the hardening process.

\begin{tabular}{cccccc}
\hline \multirow{2}{*}{ Lipid component } & \multicolumn{5}{c}{ Hardening time $(\mathrm{hr})$} \\
\cline { 2 - 6 } & 0 & 6 & 12 & 24 & 48 \\
\hline P C & 2.8 & 2.8 & 0.9 & 2.9 & 4.4 \\
S L & 1.2 & 08 & 5.4 & 1.0 & 2.4 \\
P G & $\mathbf{9 : 8}$ & 3.66 .7 & 6.8 & 5.4 & 1.5 \\
DGDG + PE & 10 & 10 & 10 & 10 & 10 \\
MGDG & 4.7 & 5.3 & 10 & 11 & 19 \\
U K & & &
\end{tabular}

The value shows the ratio of lipid component to monogalactosyl diglyceride calculated as 10 .

Fig. 3 shows TLC of non-polar lipids extracted from the algal cells treated with oligomycin (OGM) or 3-(3,4-dichlorophenyl)-1,1-dimethylurea (DCMU). A previous study (Hatano et al., 1978) revealed that OGM and DCMU remarkably inhibited the development of frost hardiness. It has been reported that OGM and DCMU specifically inhibit energy coupling mechanism in mitochondria (Lardy et al., 1964) and the electron transport system in chloroplasts (Izawa and Good., 1965), respectively. The viability of the algal cells was determined with the growth curve on the basis of $\mathrm{A}$, ,.. The algal hardiness did not develop under the conditions of light-glucose-DCMU (under light with glucose and DCMU) and dark-glucose-OGM, while developed under the conditions of dark- 


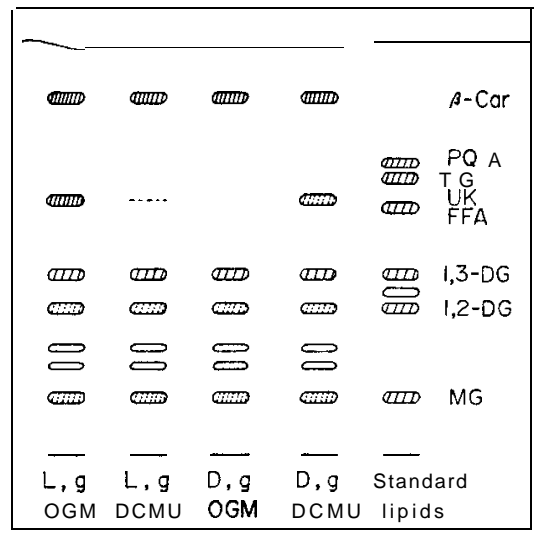

Fig. 3 Thin-layer chromatogram of non-polar lipids extracted from Chlorella ellipsoidea treated with OGM or DCMU.

Non-polar lipids were separated with n-hexane/ether/acetic acid (90/10/l, $\mathrm{v} / \mathrm{v})$. The algal cells were hardened in presence of OGM $\left(5 \times 10^{-5} \mathrm{M}\right)$ or DCMU $\left(5 \times 10^{-6} \mathrm{M}\right)$ in the light $(\mathrm{L})$ or dark (D) with $0.1 \%$ glucose $(\mathrm{g})$.

glucose-DCMLJ and light-glucose-OGM. The unknown non-polar lipid was not synthesized whenever the algal cells did not develop the frost hardiness. These results suggest that the unknown non-polar lipid is very important in the lipid metabolism associated with the hardening process.

Furthermore, the augmentation of lipid-body-like particles were observed with electron microscope in the algal cells during the hardening process (Hatano, 1978). Pomeroy and Siminovitch. (1971) have indicated that seasonal change of lipid bodies were related to the seasonal cycle of frost resistance. A parallel relationship existed between the increase of lipid-body-like particles in electronograph and the unknown non-polar lipid in TLC during the hardening process. We infer, therefore, that the unknown non-polar lipid playes a very important role in lipid metabolism associated with the hardiness change in Chlorella.

\section{REFERENCES}

Bligh, E.G. and W. J. Dyer 1959 A rapid method of total lipid extraction and purification. Can. J. Biochem. Physiol., 31: 911-917

Dubois, M.. K. A. Gilles, J. K. Hamilton, P. A. Rebers and F. Smith 1956 Colorimetric method for determination of sugars and related substances. Anal. Chem., 28: 350-356

Hatano, S., H. Sadakane, M. Tutumi and T. Watanabe 1976 a. Studies on frost hardiness in Chlorella ellipsoidea I. Development of frost hardiness of Chlorella ellipsoidea in synchronous culture. Plant \& Cell Physiol., 17: 451-458

Hatano, S., H. Sadakane, M. Tutumi and T. Watanabe 1976 b. Studies on frost hardiness in Chlorella ellipsoidea II. Effects of inhibitors of RNA and protein synthesis and surfactants on the process of hardening. Plant \& Cell Physiol., 17: 643-651

Hatano, S. 1978. Studies on frost hardiness in Chlorella ellipsoidea. In "Plant cold hardiness and freezing stress," ed. by P. H. Li and A. Sakai, Academic Press, Inc., New 
York, pp. 175-196

Hatano. S.. H. Sadakane, J. Nagayama and T. Watanabe 1978. Studies on frost hardiness in Chlorella ellipsoidea III. Changes in $\mathrm{O}_{2}$ uptake and evolution during hardening and after freeze-thawing. Plant \& Cell Physiol., 19: 917-926

Hirayama, 0. and T. Suzuki 1968 Lipid and lipoprotein complex in photosynthetic tissues part V. A comparison of lipid and pigment patterns in light-grown and dark-grown plant leaves. Agr. Biol. Chew. 32: 549-554

Hirayama, 0. and H. Matsuda 1972 A simple method for plant lipid microanalysis by combination of TLC and GLC. Agr. Bio'.Chem., 36: 2593-2596

Izawa, S. and N. E. Good 1965 The number of sites sensitive to 3-(3,4-dichlorophenyl)1,1-dimethylurea and 2-chloro-4-(2-propylamino)-6-ethylamino-s-triazine in isolated chloroplasts. Biochim. Biophys. Acta, 102: 20-38

Ian, A., de la Roche and C. J. Andrews 1973 Changes in phospholipid composition of a winter wheat cultivar during germination at $2^{\circ} \mathrm{C}$ and $24^{\circ} \mathrm{C}$. Plant Physiol.. 51: 468-473

Kuiper, P. J. C. 1970 Lipids in alfalfa leaves in relation to cold hardiness. Plant Physiol., $45: 684-686$

Lardy, H. A., J. L. Connelly and D. Johnson 1964 Antibiotics as tools form etabolic studies II. Inhibition of phosphoryl transfer in mitochondria by oligomycin and aurovertin. Biochemistry, 3 : 1961-1968

Pomeroy, M. K. and D. Siminovitch 1971 Seasonal cytological changes in secondary phloem parenchyma cells in Robinia pseudoacacia in relation to cold hardiness. Can. J. Bot.. 49: 787-795

Paula, E. F. and R. L. Heath 1970 Ozone-induced fatty acid and viability changes in Chlorella. Plant Physiol.. 55: 15-19

de la Roche, I. A., M. K. Pomeroy, P. Wineberger and M. Kate 1972 Lipid changes in wheat seedling (Triticum aesitivum) at temperatures inducing cold hardiness. Can. J. Bot.. 50: 2401-2409

Shibuya, I., H. Honda and B. Maruo 1967 A Simplified colorimetry without incineration of phosphorus in phosphatides. Agr.Biol.Chem., 31: 111-114

Siminovitch, D., Rheaume. B., Pomeroy, K. and Leapage, M. 1968 Phospholipid, protein and nucleic acid increases in protoplasm and membrane structures associated with development of extreme freezing resistance in black locust cells. Cryobiology, 5: 202225

Yoshida, S. and A. Sakai 1973 Phospholipid changes associated with the cold hardiness of cortical cells from poplar stem. Plant \& Cell Physiol., 14: 353-359 